SPORT - Science \& Practice, Vol. 11, №1, 2021, pp. 1-8.

Original scientific paper

\title{
RELATIONS OF SPEED AND SPECIFIC MOTOR ABILITIES OF SPECIAL UNIT MEMBERS ${ }^{1}$
}

\author{
UDC: 796.012.1-057.36(497.11) \\ https://doi.org/10.18485/snip.2021.11.1.en.1
}

Mihajlo Golubović ${ }^{2}$

Faculty of Sport and Physical Education, University of Niš, Serbia

Saša Veličković

Faculty of Sport and Physical Education, University of Niš, Serbia

Anđela Đošić

Faculty of Sport and Physical Education, University of Niš, Serbia

Saša Pantelić ${ }^{3}$

Faculty of Sport and Physical Education, University of Niš, Serbia

\begin{abstract}
The operational abilities of the members of the army are defined by the factors of morphology, function, levels of motor skills, health, etc. In special brigades, a high level of motor skills is required for the successful realization of assigned tasks. The most important motor skills of the Special Brigades members are endurance, strength, coordination, agility and speed, as well as balance, precision and flexibility. These parameters must be interrelated in order to expect maximum performance. The aim of the research was to determine whether there is a connection between speed and specific motor abilities of the special brigade members in the Serbian Armed Forces (SAF). The sample consisted of 74 respondents, members of the 63rd Parachute Brigade from Nis. To determine the speed, the following tests were used: sprint at $10 \mathrm{~m}, 20 \mathrm{~m}$ and $30 \mathrm{~m}$. Specific motor skills were assessed by the following tests: push-ups on the ground for 2 minutes, lifting the torso off the ground for 2 minutes, $3200 \mathrm{~m}$ running, $7 \mathrm{~m}$ rope climbing. The canonical correlation analysis was applied to determine the relationship between speed and the parameters of specific motor abilities. Data processing was conducted using the statistical package Statistica 8.0. The significance level was .05 . The results indicated the interrelation of speed and specific motor abilities with one pair of statistically significant canonical factors at the significance level of $.01(\mathrm{p}=.000)$. The isolated pair of canonical factors was explained with $43 \%$ of the common variability.
\end{abstract}

Key words: motor skills, special brigade, speed, relations

\section{INTRODUCTION}

Earlier studies show that in addition to functional and anthropometric characteristics, the level of certain motor abilities is of great importance for achieving success in certain sports, whether it is adults' (Kasum, 2001; Karalejić \& Jakovljević, 2008; Popović, 2010) or children's growth (Bubnjević et al., 2020). Also, the success of executing certain physical activities directly determines the level of individual motor abilities of an individual (Nedeljković, 2007).

Paper received: 1 March 2021, edited: 23 March 2021, accepted for publication: 23 March 2021

2 Mihajlo Golubović is a PhD student at the Faculty of Sport and Physical Education, University of Niš.

3凶panta@fsfv.ni.ac.rs 
Their share depends on a large number of factors, but also on the nature and complexity of the movement structure of a certain sports branch or discipline. An example of a very pronounced role of certain motor abilities in achieving top results is reflected, for example, in the execution of athletic movement structures, such as running, jumping or throwing events, where certain relations are manifested through a sports result (Pavlović \& Radinović, 2010). Determining the level of motor abilities and anthropological characteristics and their influence on certain indicators of physical abilities is a current problem not only in sports practice, but also in the army, which requires a high level of physical abilities. A high level of physical ability greatly affects the success in performing many tasks (Hauschild et al., 2017), and thus increases the combat readiness of the unit.

The level of operational abilities of members of the army is defined by a number of factors related to physiological and morphological characteristics, functional abilities, level of motor skills, health, etc. (Marić, 2010; Šimenko et al., 2004). In the army, and especially in special units, a high level of motor skills is required for the successful accomplishment of assigned tasks. Members of special brigades often perform training and various tasks in difficult meteorological conditions and under load (protective mask, combat equipment, protective clothing, etc.), where a large number of motor skills are pronounced. The main motor factors that are responsible for the successful execution of combat tasks by special brigades' members are cardiorespiratory endurance and strength (Družeta, 2008; Mattila et al., 2007; Mala et al., 2015). Some authors claim that mainly muscle strength and power are considered to be the most important physical attributes for executing military tasks, while aerobic abilities are given less importance (Pierce et al., 2017). Leg strength is particularly important during long marches, when leaving and returning from a training ground or a shooting range, when crossing certain obstacles, etc. (Mattila et al., 2007; Družeta, 2008; Mala et al., 2015). The importance of explosive power can be seen in mastering various training grounds, fast boarding and disembarking from combat vehicles, breaching into facilities, etc. (Pihlainen et al., 2018). In addition to strength, aerobic endurance is an important factor for the execution of training and combat tasks. Members of special brigades, as part of regular training, go on marches under load, in difficult meteorological conditions, at low and high temperatures, where the total length of the march is up to $50 \mathrm{~km}$, and the load, i.e. the weight of combat equipment, ranges from 20 to $40 \mathrm{~kg}$.

Other factors that boost the combat readiness of a unit and the level of operational capabilities include coordination, especially whole body coordination, the speed of executing complex motor tasks, agility and speed (Družeta, 2008). Also, balance, precision and flexibility are among the motor skills that are important in the army, and especially in special units (Družeta, 2008).

In order to determine the state of motor abilities of professional military personnel, and for the purpose of uniform performance of checks and assessments, a battery of tests recommended for this population group is used (Instruction for Physical Training of the Serbian Army, 2011).

The results of the research that dealt with the relations of motor abilities in members of the army were mainly based on determining the relations of body composition and other motor abilities (Glavač, 2015; Heinrich et al., 2008; Mullie et al., 2008; Crawford et al., 2011). Based on the results of the previous research (Grier et al., 2015; Nogueira et al., 2016), it was determined that BMI and body fat percentage are strongly negatively correlated with aerobic capacity and the results on military fitness tests.

Some studies have established the influence of motor skills on the realization of speed in members of the army (Maleš et al., 2004). The authors conclude that a large number of motor skills play a role in success in running, and that the integration of motor skills is omnipresent.

The aim of this study was to determine whether there is a connection between speed and specific motor skills in the members of special units in the SAF.

\section{METHOD}

\section{The sample of respondents}

The population that made up the sample of respondents was composed of the members of the 63rd Parachute Brigade in Nis. The total sample included 74 male subjects, whose average age was $33.3 \pm 5.7$. The average body height of the subjects was $178.65 \pm 6.64 \mathrm{~cm}$, body weight $84.08 \pm 9.59 \mathrm{~kg}$, while their BMI was $26.33 \pm 2.41 \mathrm{~kg} / \mathrm{m} 2$. The subjects that were included in this sample belong to the group of physically active population. As part of physical training, they exercise for 90 minutes every day. At the time of the survey, all respondents had good health status. 


\section{The sample of measuring instruments}

In accordance with the aim of the research, speed assessment tests and tests for the assessment of specific motor abilities were applied.

Speed assessment measuring instruments

The following tests were used to assess running speed (Veličković et al., 2013; Jukić et al., 2008):

- $10 \mathrm{~m}$ sprint,

- $20 \mathrm{~m}$ sprint and

- $30 \mathrm{~m}$ sprint.

Measuring instruments for the assessment of specific motor abilities

For the assessment of specific motor abilities, the tests used when checking the motor abilities in the Serbian Army were applied (Instruction for Physical Training of the Serbian Army, 2011):

- push-ups on the ground in 2 minutes,

- lifting the torso off the ground in 2 minutes,

- $3200 \mathrm{~m}$ running and

- $7 \mathrm{~m}$ rope climbing.

\section{Description of the measurement procedure}

For the sake of the research, the necessary optimal conditions were created during the measurement. The measurement of anthropometric characteristics was developed according to the method of the Centres for Disease Control and Prevention (2017), and BMI was calculated on the basis of a template proposed by the World Health Organization (WHO, 1997).

The WITTY SEM electronic timekeeping system with photocells was used to assess the speed. From the high start, the examinees were instructed to cross the distance of $30 \mathrm{~m}$ as fast as possible, and the photo-cells placed on the starting line, at $10 \mathrm{~m}, 20 \mathrm{~m}$ and $30 \mathrm{~m}$, recorded the time. The applied tests have satisfactory metric characteristics, and along with the same equipment, they have been used in other studies (Duthie et al., 2006; Jukić et al., 2008).

Specific motor skills that were tested were based on the Instruction for Physical Training in the SAF and the Standards for Assessing the Physical Ability of Military Personnel in the SAF (Instruction for Physical Training in the Serbian Army, 2011). Using a battery of tests to check physical abilities, the following parameters were assessed: repetitive endurance in the strength of the arms, shoulder girdle, chest muscles and torso, aerobic endurance and the endurance of leg muscles, as well as general physical ability. The applied tests have satisfactory metric characteristics (Jukić et al., 2008; Dhahbi et al., 2015).

Push-ups on the ground for 2 minutes,

The respondent starts performing push-ups, from the initial push-up position. An attempt to lower the whole body until the upper arms are parallel to the ground, and then return to the starting position is considered a correct push-up. With each repetition, the body must remain in a straight line. After two minutes, the test is interrupted, resulting in the number of correct repetitions over two minutes. This test has satisfactory metric characteristics, which was confirmed by a group of authors (Jukić et al., 2008).

\section{Lifting the torso off the ground for 2 minutes}

The subject performs sit-ups from the initial position: lying on the back with the knees bent at an angle of $90^{\circ}$ and the feet spread at the width of the hips, which were supported by another subject, with the arms crossed and pressed to the chest. During the test, the hands are on the chest all the time. After two minutes have elapsed, the number of correct repetitions over two minutes is entered as the result.

\section{0 m running}

Respondents start running, and immediately time measuring starts. After running the distance of $3200 \mathrm{~m}$, as a result of the test, the time during which the respondent ran the indicated section is entered. The time was entered with an accuracy of one second (minute, second).

$7 m$ rope climbing

From the initial position in which the examinee stood next to the rope and held on to the rope with one hand, they start climbing up the rope at the command of the examiner. The climbing technique was chosen by the 
respondent himself. The test ended when the subject touched a marker with their hand that indicated a height of $7 \mathrm{~m}$, and the time was entered with an accuracy of $0.10 \mathrm{~s}$ (seconds, tenths of a second).

\section{Statistical data processing}

The statistical data processing package Statistica 8.0 for Windows (StatSoft, Inc., Tulsa, OK) was used for processing and analysis of raw data.

The basic parameters of descriptive statistics and distribution were calculated (arithmetic mean, standard deviation, minimum and maximum value, range, curvature coefficient - skewness, roundness coefficient - kurtosis). Canonical correlation analysis was used to determine the relationship between speed and the parameters of specific motor abilities. The canonical correlation coefficient, the percentage of common variance, the significance of the connections of the investigated space, the degree of freedom and the statistical significance of the canonical correlation analysis were calculated. The significance level was .05.

\section{RESULTS}

Table 1 shows the parameters of descriptive statistics and distribution of applied variables for estimating speed and specific motor abilities.

The mean value of the $10 \mathrm{~m}$ sprint is $2.01 \pm 0.13 \mathrm{~s}$, the $20 \mathrm{~m}$ sprint is $3.43 \pm 0.20 \mathrm{~s}$, while the mean value of the $30 \mathrm{~m}$ sprint is $4.78 \pm 0.28 \mathrm{~s}$. Skewness values indicate that there is no expressed asymmetry. The results have a slightly positive asymmetry (epicurticity), which indicates that there are several good results, but it can be stated that they are within the permissible deviations. The lowest value of the curvature coefficient (Skew) is .42 for the $10 \mathrm{~m}$ sprint, while the highest is 1.12 for the $30 \mathrm{~m}$ sprint. The values of kurtosis (Kurt) indicate that the variables for estimating the velocity deviate relatively little from the normal distribution, i.e. that they are slightly incompact. The lowest value of the rounding coefficient (Kurtosis) is .61 for the $10 \mathrm{~m}$ sprint, while the highest is 2.10 for the $30 \mathrm{~m}$ sprint.

The results of the mean values of tests for the assessment of specific motor abilities are the following: for push-ups for $2 \min 65.86 \pm 11.85$, for lifting the torso for $2 \min 75.22 \pm 11.76$, for $3200 \mathrm{~m}$ running $14.53 \pm 1.31 \mathrm{~min}$ and for $7 \mathrm{~m}$ rope climbing $9.96 \pm 2.17 \mathrm{~s}$. Skewness values indicate that there is no pronounced asymmetry. The results have a slightly positive asymmetry (epicurticity), which indicates that there are several good results, but they are within the allowed tolerance. The measured values of the coefficient of curvature (Skew) range from .13 for lifting the torso for $2 \mathrm{~min}$ to .89 for $7 \mathrm{~m}$ rope climbing. The values of kurtosis (Kurt) indicate that the variables for the assessment of motor skills deviate relatively little from the normal distribution, i.e. that they are slightly incompact and range from --.03 in the test torso lift for $2 \mathrm{~min}$ to 1.97 in the test of $7 \mathrm{~m}$ rope climbing.

Table 1. Basic parameters of descriptive statistics $(n=74)$

\begin{tabular}{lccccccc}
\hline & Mean & SD & Min & Max & Range & Skew & Kurt \\
\hline Sprint 10m [s] & 2,01 &, 13 & 1,71 & 2,39 &, 68 &, 42 &, 61 \\
\hline Sprint 20m [s] & 3,43 &, 20 & 3,09 & 4,13 & 1,04 &, 93 & 1,72 \\
\hline Sprint 30m [s] & 4,78 &, 28 & 4,31 & 5,78 & 1,47 & 1,12 & 2,10 \\
\hline Push-ups for 2 min [number] & 65,86 & 11,85 & 42,00 & 106,00 & 64,00 &, 70 & 1,79 \\
\hline Lifting the torso for 2 min[number] & 75,22 & 11,76 & 48,00 & 109,00 & 61,00 &, 13 &,- 03 \\
\hline 3200m running[min] & 14,53 & 1,31 & 12,10 & 18,40 & 6,30 &, 50 &, 43 \\
\hline 7m rope climbing [s] & 9,96 & 2,17 & 5,30 & 18,00 & 12,70 &, 89 & 1,97 \\
\hline
\end{tabular}

Legend: Mean - arithmetic mean; SD - standard deviation; Min - minimum value; Max - maximum value; Range - range; Skew - curvature coefficient; Kurt - coefficient of roundness

The determined interrelations of parameters for speed assessment range from .90 to .98 , while the correlation of parameters for the assessment of specific motor abilities ranged from .34 to .80 . It should be noted that in the interrelation of parameters for the assessment of parameters of specific motor abilities, both positive and negative values were determined (these values are not shown in the table). 
Based on the results shown in the Table 2, where cross-correlations of parameters for assessing speed and specific motor skills are shown, a weak negative correlation can be found between the variables of the $10 \mathrm{~m}$ sprint and push-ups for $2 \mathrm{~min}(-.46)$, as well as between the $10 \mathrm{~m}$ sprint and lifting the torso for $2 \mathrm{~min}(-.49)$.

Table 2. Cross-correlations of parameters for estimating speed and specific motor abilities

\begin{tabular}{lcccc}
\hline & $\begin{array}{c}\text { Push-ups } \\
\text { for } 2 \mathrm{~min}\end{array}$ & $\begin{array}{c}\text { Lifting the torso } \\
\text { for } 2 \mathrm{~min}\end{array}$ & 3200m running & $\begin{array}{c}7 \mathrm{~m} \text { rope } \\
\text { climbing }\end{array}$ \\
\hline Sprint $10 \mathrm{~m}$ & -.46 & -.49 & .21 & .43 \\
\hline Sprint $20 \mathrm{~m}$ & -.50 & -.53 & .21 & .52 \\
\hline Sprint $10 \mathrm{~m}$ & -.50 & -.53 & .22 & .54 \\
\hline
\end{tabular}

There is a weak positive connection between the $10 \mathrm{~m}$ sprint and the $3200 \mathrm{~m}$ run $(.21)$, as well as between the $10 \mathrm{~m}$ sprint and the $7 \mathrm{~m}$ rope climbing (.43). Observing the correlations of the variable $20 \mathrm{~m}$ sprint with specific motor abilities, it was found that there are significant relations with push-ups for $2 \mathrm{~min}(-.50)$ and torso lift for $2 \mathrm{~min}$ $(-.53)$, as well as weak positive relations with $3200 \mathrm{~m}$ running (.21) and $7 \mathrm{~m}$ rope climbing (.52). Significant negative correlations with push-ups for $2 \mathrm{~min}(-.50)$ and lifting the torso for $2 \mathrm{~min}(-.53)$ can also be found in the $30 \mathrm{~m}$ sprint, while there are weak positive correlations with $3200 \mathrm{~m}$ running $(.22)$ and significant positive correlations with the $7 \mathrm{~m}$ rope climbing (.54).

The canonical correlation analysis was applied to determine the relationship between the parameters for estimating speed and the parameters for estimating specific motor abilities. The results shown in the Table 3 show that speed and specific motor abilities are interrelated with one pair of statistically significant canonical factors at a significance level of .01 ( $\mathrm{p}=.000)$. An isolated pair of canonical factors explains $43 \%$ (Can R-sqr.43) of the common variability.

Table 3. Canonical correlations of speed and specific motor parameters

\begin{tabular}{|c|c|c|c|c|c|}
\hline & Can R & Can R-sqr. & Chi-sqr. & df & $\mathrm{p}$ \\
\hline 0 & .66 & .43 & 42,50 & 12 & $.000 * *$ \\
\hline 1 & .17 & .03 & 3,22 & 6 & .780 \\
\hline 2 & .13 & .02 & 1,09 & 2 & .579 \\
\hline \multicolumn{6}{|c|}{$\begin{array}{l}\text { Legend: Can R - canonical correlation coefficient; Can R-sqr. - percentage of common variance; } \\
\text { Chi-sqr. - significance of connections of the researched space; df - degree of freedom; } p \text { - statistical } \\
\text { significance; significance level: }{ }^{* *} \mathrm{p}<.01 \text {. }\end{array}$} \\
\hline
\end{tabular}

By analyzing the results of the velocity factor structure (Table 4), it can be concluded that the $30 \mathrm{~m}$ sprint (.98) and the $20 \mathrm{~m}$ sprint (.96) have the highest positive projections on the first canonical factor, and therefore the most conditioned results in all of the tests of specific motor abilities, so this factor can be defined as the speed factor. The 10m sprint (.83) has slightly lower, but still significant influence on the manifestations of specific motor abilities. Observing the results of the factor structure of specific motor abilities, it is noticed that the highest projections on the first canonical factor are featured by $7 \mathrm{~m}$ rope climbing (.85), then lifting the torso for $2 \mathrm{~min}(-.80)$ and push-ups for $2 \mathrm{~min}(-.74)$, and this factor can be called the power factor.

Table 4. Factor structure of isolated canonical factors of speed and specific motor abilities

\begin{tabular}{lc|lc}
\hline & Root 1 & \multicolumn{2}{c}{ Root 1} \\
\hline Sprint $10 \mathrm{~m}$ & .83 & Push-ups for 2 min & -.74 \\
\hline Sprint $20 \mathrm{~m}$ & .96 & Lifting the torso for 2 min & -.80 \\
\hline Sprint $10 \mathrm{~m}$ & .98 & 3200m running & .31 \\
\hline & & 7m rope climbing & .85 \\
\hline
\end{tabular}




\section{DISCUSSION}

Comparing the descriptive parameters of specific motor abilities of the tested sample with the recommended standards for physical testing (Instructions for Physical Training of the Serbian Army, 2011), it can be concluded that the level of specific motor abilities of the respondents is very high. A high level of motor skills affects the success of executing a large number of tasks (Hauschild et al., 2017), and thus increases combat readiness. The mean value in the push-up discipline is higher than the recommended standard (48), which indicates that in the tested sample the strength of the pectoral muscles and arm muscles is at a high level, as indicated by the results of other authors (Vaara et al., 2012). The repetitive strength of the torso (lifting the torso from the ground) is significantly higher than the standard (60), but a relatively large range was found, which indicates that there is a large difference in the repetitive strength of some subjects. The results of studies of foreign armies (Pihlainen et al., 2018) point to the repetitive strength of the troops as one of the factors that show the highest correlation with the results on military training grounds, so the values obtained in this study are in line with expectations. In the discipline of $7 \mathrm{~m}$ rope climbing, the obtained average values are lower by 4.04 seconds than the prescribed standard (Instructions for Physical Training of the Serbian Army, 2011), which are better results in this case. Based on the obtained results, it can be stated that the examinees included in the research have an enviable level of climbing technique as well as repetitive strength. The values of aerobic abilities estimated by the $3200 \mathrm{~m}$ running test are also at a high level. Comparing the mean value with the standard of physical tests, it can be noticed that the running time is 1.07 minutes less than the recommended values, which in this case is a better result. Other studies indicate that aerobic abilities are an important factor for the successful performance of assigned combat tasks (Hauschild et al., 2017) and that they must be at a high level, which is consistent with the results of our study.

Table 2 shows the cross-correlations of the parameters for estimating speed and specific motor abilities. Analysing the measurement results, it can be concluded that there is a correlation between the parameters of speed and repetitive power, as well as that the speed is somewhat weaker in correlation with aerobic abilities. Positive correlations can be noticed between the tests for assessing the speed and discipline of push-ups on the ground, which indicate that an increase in speed abilities leads to a significant increase in the repetitive strength of the chest and arm muscles. Similar relationships can be observed between tests for assessing the speed and lifting the torso off the ground, which leads to the conclusion that sprinting abilities have a significant positive effect on repetitive strength. The results of this research coincide with the results of previously conducted studies (Pavlović \& Radinović, 2010). Some correlation is observed between speed assessment tests and $3200 \mathrm{~m}(.21)$ running results, but they are weaker than repetitive power. The obtained results indicate that with the improvement of sprinting abilities, i.e. speed, there is no significant increase in aerobic endurance. Similar results have been obtained by other authors, who indicate high correlations between sprint, strength and power (Sleivert \& Taingahue, 2004; Cronin et al., 2008; Cormie et al., 2010), but a weak connection with aerobic capacity. Tests that assess speed at $10 \mathrm{~m}, 20 \mathrm{~m}$ and $30 \mathrm{~m}$ sprint take place in anaerobic conditions, while the 3200 running discipline is one of the tests to check aerobic endurance, so this can explain such a small correlation between these tests. Significant positive correlations also exist between the tests that assess speed and $7 \mathrm{~m}$ rope climbing. Significant correlations between speed and the results of rope climbing can be explained by the fact that legs are also used during the rope climbing technique, so it can be concluded that with the increase of sprinting abilities, the result in rope climbing will also improve.

The presented relations between the parameters for estimating speed and the parameters for estimating specific motor abilities indicate that $t$ he spaces of speed and specific motor abilities are interconnected with one pair of statistically significant canonical factors at the significance level of .05 . The obtained results indicate that the change of one space affects the changes of another. Other authors obtained similar results. The research of Young et al. (1995), Plisk (2008), Parchmann \& McBride (2011), Triplett et al. (2012) and Maleš et al. (2004) proved the existence of the connections between speed and the parameters of individual motor skills.

\section{CONCLUSION}

The research was conducted with the aim of determining the relations between speed and specific motor abilities in special units' members of the SAF. Based on the results of cross-correlations and canonical correlation analysis between speed and specific motor abilities, it was determined that there is a statistically significant 
correlation between speed and specific motor abilities in special units' members. The results obtained by this research showed that speed has a statistically significant effect on certain specific motor abilities. The obtained results are in accordance with other studies. Future research should focus on determining the relationship between other anthropological parameters of members of the special brigade and specific motor skills in order to obtain data on possible relationships and propose programs to improve their performance.

\section{REFERENCES}

1. Bubnjević, P., Vukićević, V., Lukić, N. \& Miličković, V. (2020). Povezanost rezultata testova eksplozivne snage i brzine kod mladih fudbalera. Sport - Nauka i praksa, 10(1), 29-38.

2. Centers for Disease Control and Prevention. (2013). National Health and Nutrition Examination Survey (NHANES) Anthropometry Procedures Manual. US Department of Health and Human Services, Centers for Disease Control and Prevention.

3. Cormie, P., McGuigan, M.R. \& Newton, R.U. (2010). Adaptations in athletic performance after ballistic power versus strength training. Medicine \& Science in Sports \& Exercise, 42(8), 1582-1598.

4. Crawford, K., Fleishmati, K., Abt, P.J., Sell, C.T., Lovalekar, M., Nagai, T., Deluzio, J., Rowe, S.R., McGrail, A.M. \& Lephart, M.S. (2011). Less Body Fat Improves Physical and Physiological Performance in Army Soldiers. Military Medicine, 176(1), 35-43.

5. Cronin, J.B. \& Templeton, R.L. (2008). Timing light height affects sprint times. The Journal of Strength \& Conditioning Research, 22(1), 318-320.

6. Dhahbi, W., Chaouachi, A., Padulo, J., Behm, D.G. \& Chamari, K. (2015). Five-meter rope-climbing: a commando-specific power test of the upper limbs. International Journal of Sports Physiology and Performance, 10(4), 509-515.

7. Družeta, K. (2008). Dijagnostika kondicijske pripremljenosti djelatnih vojnih osoba Oružanih snaga Republike Hrvatske. (Diplomski rad). Zagreb: Kineziološki fakultet Sveučilišta u Zagrebu.

8. Duthie, G.M., Pyne, D.B., Ross, A.A., Livingstone, S.G. \& Hooper, S.L. (2006). The reliability of ten-meter sprint time using different starting techniques. The Journal of Strength \& Conditioning Research, 20(2), 246251.

9. Glavač, B.T. (2015). Motoričke sposobnosti, morfološki status i životne navike kod pripadnika Vojske Srbije (Doktorska disertacija). Beograd: Univerzitet u Beogradu, Fakultet sporta i fizičkog vaspitanja.

10. Grier, T., Canham-Chervak, M., Sharp, M. \& Jones, B. H. (2015). Does body mass index misclassify physically active young men. Preventive Medicine Reports, 2, 483-487.

11. Hauschild, V.D., DeGroot, D.W., Hall, S.M., Grier, T.L., Deaver, K.D., Hauret, K.G. \& Jones, B.H. (2017). Fitness tests and occupational tasks of military interest: a systematic review of correlations. Occupational and Environmental Medicine, 74(2), 144-153.

12. Heinrich, M.K., Jitnarin, N., Suminski, R.R., Berkel, L.V., Hunter, M.C., Alvarez, L., Antionette, R., Brundige, R.A., Peterson, L.A., John, P., Foreyt, P. J., Haddock, K. \& Poston, S.C.W. (2008). Obesity classification in military personnel: A comparison of body fat, waist circumference, and body mass index measurements. Military Medicine, 173(1), 67-73.

13. Jukić, I., Vučetić, V., Aračić, M., Bok, D., Dizdar, D., Sporiš, G. \& Križanić, A. (2008). Dijagnostika kondicijske pripremljenosti vojnika. Zagreb: Kineziološki fakultet Sveučilišta u Zagrebu i Institut za istraživanje i razvoj obrambenih sustava.

14. Karalejić, M. \& Jakovljević, S. (2008). Teorija i metodika košarke. Beograd: Fakultet sporta i fizičkog vaspitanja.

15. Kasum, G. (2001). Influence of morphologic and motoric features of students of the Faculty of physical culture in Belgrade on the efficiency of wrestling curriculum. Fizička kultura, 55(1-4), 42-48.

16. Mala, J., Szivak, T.K., Flanagan, S.D., Comstock, B.A., Laferrier, J.Z., Maresh, C.M. \& Kraemer, W.J. (2015). The role of strength and power during performance of high intensity military tasks under heavy load carriage. US Army Medical Department Journal, 3-12.

17. Maleš, B., Dragičević, S. \& Erceg, M. (2004). Utjecaj motoričkih sposobnosti na realizaciju sprinta kod ročnih vojnika. Školski vjesnik, 1-2; 111-117. 
18. Marić, L. (2010). Razvoj motoričkih sposobnosti i njihove relacije sa motoričkom efikasnošću studenata Vojne akademije. Doktorska disertacija, Novi Sad: ACIMSI.

19. Mattila, V.M., Tallroth, K.A.J., Marttinen, M. \& Pihlajamäki, H. (2007). Physical fitness and performance. Body composition by DEXA and its association with physical fitness in 140 conscripts. Medicine and Science in Sports and Exercise, 39(12), 2242-2247.

20. Mullie, P., Vansant, G. Hulens, M., Clarys, P. \& Degrave, E. (2008). Evaluation of body fat estimated from body mass index and impedance in belgian male military candidates: Comparing two methods for estimating body composition. Military Medicine, 173(3), 266-70.

21. Nedeljković, A. (2007). Uticaj telesnih dimenzija na ispoljavanje maksimalne snage mišića (Doktorska disertacija). Beograd: Fakultet sporta i fizičkog vaspitanja.

22. Nogueira, E.C., Porto, L.G.G., Nogueira, R.M., Martins, W.R., Fonseca, R.M., Lunardi, C.C. \& de Oliveira, R.J. (2016). Body composition is strongly associated with cardiorespiratory fitness in a large Brazilian military firefighter cohort: the Brazilian firefighters study. The Journal of Strength \& Conditioning Research, 30(1), 33-38.

23. Parchmann, C.J. \& McBride, J.M. (2011). Relationship between functional movement screen and athletic performance. The Journal of Strength \& Conditioning Research, 25(12), 3378-3384.

24. Pavlović, R. \& Radinović, Z. (2010). Motoričke sposobnosti kao faktori uspjeha u atletici. Sport i zdravlje, 5(2), 96-103.

25. Pierce, J.R., De Groot, D.W., Grier, T.L., Hauret, K.G., Nindl, B.C., East, W.B... \& Jones, B.H. (2017). Body mass index predicts selected physical fitness attributes but is not associated with performance on military relevant tasks in US Army Soldiers. Journal of Science and Medicine in Sport, 20, S79-S84.

26. Pihlainen, K., Santtila, M., Häkkinen, K. \& Kyröläinen, H. (2018). Associations of physical fitness and body composition characteristics with simulated military task performance. The Journal of Strength \& Conditioning Research, 32(4), 1089-1098.

27. Plisk S. (2008). Speed, agility, and speedendurance development. In: Baechle T.R. and Earle R.W. eds., Essentials of Strength Training and Conditioning - NSCA (3rd ed) (pp. 458-485). Champaign, IL: Human Kinetics.

28. Popović, B. (2010). The influence of morphological and motor characteristics of students of the Faculty of Physical Education in Belgrade on the efficiency of mastering judo curriculum. Fizička kultura, 64(1), 62-71.

29. Sleivert, G. \& Taingahue, M. (2004). The relationship between maximal jump-squat power and sprint acceleration in athletes. European Journal of applled Physiology, 91(1), 46-52.

30. Šimenko, J., Čoh, M., Škof, B., Zorec, B. \& Milić, R. (2014). Comparison of Some Morphological and Physiological Characteristics of Slovenian Police Special Unit and American Special Forces SWAT. Journal of Criminal Justice and Security, (3), 312-320.

31. Triplett, N.T., Erickson, T.M. \& McBride, J.M. (2012). Power associations with running speed. Strength \& Conditioning Journal, 34(6), 29-33.

32. Uputstvo za fizičku obuku u Vojsci Srbije (2011). Uprava za obuku i doktrinu. Beograd: Generalštab Vojske Srbije.

33. Vaara, J.P., Kyröläinen, H., Niemi, J., Ohrankämmen, O., Häkkinen, A., Kocay, S. \& Häkkinen, K. (2012). Associations of maximal strength and muscular endurance test scores with cardiorespiratory fitness and body composition. The Journal of Strength \& Conditioning Research, 26(8), 2078-2086.

34. Veličković, S., Petković, D. \& Petković, E. (2013). The effects of programmed physical preparation on the transformation of motor skills of young soldiers of various specialties. Military Operations Research, 18(2), 49-59.

35. Young, W., Mc Lean, B. \& Ardagna, J. (1995). Relationship between strength qualities and sprinting performance. Journal of Sports Medicine and Physical Fitness, 35(1), 13-19. 